\title{
Rapid growth in greenhouse gas emissions from the adoption of industrial-scale aquaculture
}

Yuan, J.J.; Xiang, J.; Liu, Deyan; Kang, Hojeong; He, Teihu; Kim, S.; Lin, Y.; Freeman, Christopher; Ding, W.X.

\section{Nature Climate Change}

DOI:

$10.1038 / \mathrm{s} 41558-019-0425-9$

Published: 01/04/2019

Peer reviewed version

Cyswllt i'r cyhoeddiad / Link to publication

Dyfyniad o'r fersiwn a gyhoeddwyd / Citation for published version (APA):

Yuan, J. J., Xiang, J., Liu, D., Kang, H., He, T., Kim, S., Lin, Y., Freeman, C., \& Ding, W. X. (2019). Rapid growth in greenhouse gas emissions from the adoption of industrial-scale aquaculture. Nature Climate Change, 9(4), 318-322. https://doi.org/10.1038/s41558-019-0425-9

\footnotetext{
Hawliau Cyffredinol / General rights

Copyright and moral rights for the publications made accessible in the public portal are retained by the authors and/or other copyright owners and it is a condition of accessing publications that users recognise and abide by the legal requirements associated with these rights. study or research

- Users may download and print one copy of any publication from the public portal for the purpose of private

- You may not further distribute the material or use it for any profit-making activity or commercial gain

- You may freely distribute the URL identifying the publication in the public portal?
}

Take down policy

If you believe that this document breaches copyright please contact us providing details, and we will remove access to the work immediately and investigate your claim. 
1 Rapid growth in greenhouse gas emissions from the adoption of industrial-scale aquaculture

2

3 Running head: Industrial-scale aquaculture increases global warming

4 Junji Yuan $^{1 \dagger}$, Jian Xiang ${ }^{1 \dagger}$, Deyan Liu ${ }^{1}$, Hojeong Kang ${ }^{2}$, Tiehu $\mathrm{He}^{1,3}$, Sunghyun Kim ${ }^{1 \star}$, Yongxin

$5 \operatorname{Lin}^{1}$, Chris Freeman ${ }^{4 \star}$, Weixin Ding ${ }^{1 \star}$

$6{ }^{1}$ State Key Laboratory of Soil and Sustainable Agriculture, Institute of Soil Science, Chinese

7 Academy of Sciences, Nanjing 210008, China.

$8 \quad 2$ School of Civil and Environmental Engineering, Yonsei University, Seoul 120-749, Korea

$9 \quad{ }^{3}$ University of Chinese Academy of Sciences, Beijing 100049, China

10

$11 \dagger$ These authors contributed equally to this work.

${ }^{4}$ School of Natural Sciences, Bangor University, Gwynedd LL57 2UW, UK

$\ddagger$ Present address: Smithsonian Environmental Research Center, Edgewater, MD 21037, USA

\section{${ }^{\star}$ Author for correspondence:}

Weixin Ding: Tel: 0086-25-86881527; Fax: 0086-25-86881000; Email: wxding@,issas.ac.cn

Chris Freeman: Tel: 44-1248-382353; Fax: 44-1248370731; Email: c.freeman@,bangor.ac.uk

Article type: Primary Research Article

Length of the text, methods and legends: 2,099, 2,466 and 229 words, respectively

The number of references: 30

The number of figures and tables: 2 figures and 2 tables

Final size of figures and tables: Fig. 1, $31 \mathrm{~Kb}, 2$-column width; Fig. 2, $52 \mathrm{~Kb}, 1$-column width 


\section{Abstract}

Fisheries capture has plateaued, creating ever-greater reliance on aquaculture to feed growing populations. Aquaculture volumes now exceed those of capture fisheries globally ${ }^{1,2}$, with China dominating production through major land-use change; more than half of Chinese freshwater aquaculture systems having been converted from paddy fields ${ }^{1,3}$. However, the greenhouse gas (GHG) implications of this expansion have yet to be effectively quantified. Here we measure year-round methane $\left(\mathrm{CH}_{4}\right)$, nitrous oxide $\left(\mathrm{N}_{2} \mathrm{O}\right)$ and carbon dioxide $\left(\mathrm{CO}_{2}\right)$ emissions from paddy fields and new, extensively managed crab aquaculture ponds. The conversion increased associated global warming potentials (GWP) from $8.15 \pm 0.43$ to $28.0 \pm 4.1 \mathrm{Mg} \mathrm{CO}_{2}$ eq ha ${ }^{-1}$, primarily due to increased $\mathrm{CH}_{4}$ emission. After compiling a worldwide database of different freshwater aquaculture systems, the top 21 producers were estimated to release $6.04 \pm 1.17 \mathrm{Tg} \mathrm{CH}_{4}$ and $36.7 \pm 6.1 \mathrm{Gg} \mathrm{N}_{2} \mathrm{O}$ in 2014. We found that $80.3 \%$ of total $\mathrm{CH}_{4}$ emitted originated in shallow earthen aquaculture systems, with far lower emissions from intensified systems with continuous aeration ${ }^{4}$. We therefore propose greater adoption of aerated systems is urgently required to address globally significant rises in $\mathrm{CH}_{4}$ emission from the conversion of paddy fields to aquaculture. 
With increasing demand for animal proteins due to rising populations and a leveling off in capture fisheries, global aquaculture production has increased by $500 \%$ since the late-1980s, and now represents a major global industry ${ }^{1}$. In 2014, aquaculture volume amounted to 101 million tons (Mt) and is projected to reach $230 \mathrm{Mt}$ by 2030 , accounting for $62 \%$ of global fish and shellfish supply for human consumption ${ }^{1,2}$. This ever-expanding aquaculture sector relies heavily on application of aquafeeds $^{5,6}$ which increase nutrient loadings and carbon (C) burial in aquaculture systems and adjacent water bodies ${ }^{7,8}$. Only $25 \%(11-36 \%)$ of the nitrogen $(\mathrm{N})$ consumed by fish was converted to biomass with the remainder excreted into water as un-ionized ammonia ${ }^{9,10}$. Likewise, a substantial proportion of feed $\mathrm{C}$ was transformed to $\mathrm{CO}_{2}$ and $\mathrm{CH}_{4}$ by animals and microbes ${ }^{11}$ or buried in aquaculture systems ${ }^{7}$. In 2016, about $10.9 \mathrm{Tg} \mathrm{C}$ and $1.82 \mathrm{Tg} \mathrm{N}$ from the $39.9 \mathrm{Mt}$ aquafeeds were estimated to be discharged to environments in global aquaculture ${ }^{12}$. Moreover, fertilizers are widely used in the extensive and semi-intensive aquaculture systems to stimulate phytoplankton production $^{13}$. These intensive $\mathrm{C}$ and $\mathrm{N}$ loadings have the potential to drive aquaculture systems to become major anthropogenic sources of $\mathrm{CH}_{4}$ and $\mathrm{N}_{2} \mathrm{O}$ emissions.

Williams \& Crutzen ${ }^{14}$ tentatively estimated $\mathrm{N}_{2} \mathrm{O}$ emission from the aquaculture sector at $0.09 \mathrm{Tg}$ in 2008, accounting for $0.33 \%$ of global $\mathrm{N}_{2} \mathrm{O}$ emission. Using the $\mathrm{N}_{2} \mathrm{O}$ emission factor of influent $\mathrm{N}$ $\left(\mathrm{EF}_{\mathrm{N}}=1.80 \%\right)$ in wastewater treatment plants ${ }^{15}$, global $\mathrm{N}_{2} \mathrm{O}$ emission from aquaculture was estimated to increase from $0.15 \mathrm{Tg}$ in 2009 to $0.60 \mathrm{Tg}$ in 2030 , which could contribute $5.72 \%$ of global anthropogenic $\mathrm{N}_{2} \mathrm{O}$ emission ${ }^{10}$. However, large uncertainties in these estimates may arise from differences in management levels ${ }^{16,17}$ and yield difference between species ${ }^{17,18}$. Besides $\mathrm{N}_{2} \mathrm{O}$, aquaculture ponds could be important anthropogenic $\mathrm{CH}_{4}$ sources with characteristics of intensive $\mathrm{C}$ loading, shallow water and frequent mixing ${ }^{19}$. To date, $>40 \%$ of worldwide aquaculture production has been carried out in earthen ponds, while estimates of overall $\mathrm{CH}_{4}$ budgets in global aquaculture 
remain scarce.

China is the world's largest aquaculture producer, contributing $\sim 60 \%$ of global volume ${ }^{1}$; furthermore the volume and area of that aquaculture is steadily rising ${ }^{3}$. Above $70 \%$ of Chinese freshwater aquaculture production is carried out in extensive and semi-intensive earthen ponds ${ }^{3}$. More and more paddy fields have been, and will continue to be, converted to aquaculture ponds. They currently account for $51.3 \%$ of Chinese inland fish ponds ${ }^{3,18}$. There is clearly an urgent need for greater appreciation of the costs associated with GHG emissions incurred during the ongoing unprecedented levels of conversion of paddy fields towards industrial-scale aquaculture.

\section{Effect of conversion of paddy field to aquaculture on GHG emission}

We measured year-round fluxes of $\mathrm{CH}_{4}, \mathrm{~N}_{2} \mathrm{O}$ and $\mathrm{CO}_{2}$ from three adjacent crab aquaculture ponds converted from paddy fields 12 years ago and neighboring paddy fields (PF) in the Tai Lake basin $\left(31^{\circ} 02^{\prime} \mathrm{N}, 120^{\circ} 25^{\prime} \mathrm{E}\right.$; Supplementary Figs. 1 and 2) during $2013-2014$. Wheat-rice rotation is the typical cropping system in this region. Urea was applied in PF at 150 and $280 \mathrm{~kg} \mathrm{~N} \mathrm{ha}^{-1}$ during wheat and rice seasons, respectively. Crab ponds differed in size and water depth (Supplementary Table 1). They were not equipped with aerators but were fertilized during culturing. Chinese mitten crab (Eriocheir sinensis) were fed with commercial feed pellets, trash fish and corn seeds at the same rate in each pond during crab production period from March to October. Annual $\mathrm{C}$ and $\mathrm{N}$ inputs in crab ponds were $1.20 \mathrm{Mg} \mathrm{Cha}^{-1}$ and $244 \mathrm{~kg} \mathrm{~N} \mathrm{ha}^{-1}$, respectively (Supplementary Tables 2-4).

Annual $\mathrm{CH}_{4}$ emission in PF was $218 \pm 7.28 \mathrm{~kg} \mathrm{CH}_{4} \mathrm{ha}^{-1}$ (Fig. 1a), which was located in the upper end of the previously reported ranges (98.3-240 kg CH $\mathrm{ha}^{-1}$ ) for paddy fields without organic amendment in this area ${ }^{20}$. However, conversion from PF to crab ponds sharply increased 
$\mathrm{CH}_{4}$ emission to $962 \pm 62 \mathrm{~kg} \mathrm{CH}_{4} \mathrm{ha}^{-1}$; this value was higher than the summarized amount of 572 $\mathrm{kg} \mathrm{CH}_{4} \mathrm{ha}^{-1}$ in permanently inundated temperate wetlands and the default emission factor $(900 \mathrm{~kg}$ $\mathrm{CH}_{4} \mathrm{ha}^{-1}$ ) for tropical inland freshwater wetlands proposed by the Intergovernmental Panel on Climate Change (IPCC; ref. 21).

The $\mathrm{CH}_{4} \mathrm{EF}_{\mathrm{C}}$ of $\mathrm{C}$ inputs from feeds and fertilizer in crab ponds was estimated at up to $60.0 \%$ (Table 1), which may be attributed to the enhanced availability of labile organic substrates and highly anaerobic environment in crab ponds. The $\mathrm{C}$ output as harvested crab was $0.19 \mathrm{Mg} \mathrm{C} \mathrm{ha}^{-1}$ (Supplementary Table 4), accounting for $16.1 \%$ of the $\mathrm{C}$ inputs excluding the photosynthates by submerged macrophytes. The remaining $1.04 \mathrm{Mg} \mathrm{C} \mathrm{ha}^{-1}$ was deposited into sediments as unconsumed feed and feces, which led mean dissolved organic C (DOC) concentrations in pond sediments to reach 7.97-fold greater than that of PF (Supplementary Table 1). Additionally, organic compounds in feed remnants and feces such as starch and protein can be more easily decomposed ${ }^{22}$ to methanogenic substrates than crop residues in PF. Moreover, pond sediments were permanently inundated, thereby creating anaerobic environments ideal for methanogenesis.

Annual $\mathrm{N}_{2} \mathrm{O}$ emission in $\mathrm{PF}$ was $7.11 \pm 0.23 \mathrm{~kg} \mathrm{~N}_{2} \mathrm{O}$ ha $^{-1}$ (Fig. 1b). The $\mathrm{EF}_{\mathrm{N}}$ of fertilizer-N applied was $1.05 \%$, closing to the IPCC default value $(1.00 \%)$ for agricultural soils ${ }^{23}$. Conversion from PF to crab ponds significantly decreased annual $\mathrm{N}_{2} \mathrm{O}$ emission by $95.4 \%$ to $0.33 \pm 0.07 \mathrm{~kg}$ $\mathrm{N}_{2} \mathrm{O}$ ha ${ }^{-1}$, with an $\mathrm{EF}_{\mathrm{N}}$ of $0.09 \pm 0.02 \%$ (Table 1). The lower $\mathrm{N}_{2} \mathrm{O}$ emission in crab ponds was disproportionate to the differences in $\mathrm{N}$ application rates ( $244 \mathrm{vs} 430 \mathrm{~kg} \mathrm{~N} \mathrm{ha}^{-1}$ ), let alone the relatively higher total inorganic N content in pond sediments (Supplementary Tables 1). Nitrous oxide is derived from both nitrification and denitrification, although denitrification produces more $\mathrm{N}_{2} \mathrm{O}$ (ref. 24). It is likely that the much lower redox potential $(-124$ to $-160 \mathrm{mV}$ ) suppressed nitrification in pond sediments, which reduced overall $\mathrm{NO}_{3}{ }^{-}$concentrations to $<1 \mathrm{mg} \mathrm{N} \mathrm{kg}^{-1}$. This 
concentration was lower than the threshold value of $5 \mathrm{mg} \mathrm{N} \mathrm{kg}^{-1}$ for active denitrification ${ }^{25}$. Moreover, the high DOC concentrations and anaerobic conditions permit $\mathrm{N}_{2} \mathrm{O}$ to be further reduced to $\mathrm{N}_{2}$ through denitrification ${ }^{26}$.

Using the net ecosystem C balance method, annual loss of soil organic C (SOC) in PF was estimated to be $0.04 \pm 0.05 \mathrm{Mg} \mathrm{C} h a^{-1}$ (Table 1), which fell in the range of -0.27 to $0.67 \mathrm{Mg} \mathrm{C} \mathrm{ha}{ }^{-1}$ estimated previously in paddy fields of Tai Lake basin ${ }^{27}$. The $\mathrm{CO}_{2}$ fluxes measured by transparent chambers in crab ponds were regarded as net ecosystem exchange. On an annual basis, crab ponds were weak net $\mathrm{CO}_{2}$ sources, releasing 0.13-1.99 $\mathrm{Mg} \mathrm{CO}_{2}$ ha $^{-1}$ (Fig. 1c).

Conversion from PF to extensive crab ponds increased the 100-yr GWP from $8.15 \pm 0.43$ to $28.0 \pm 4.1 \mathrm{Mg} \mathrm{CO}_{2}$ eq ha ${ }^{-1}$, mainly due to increased $\mathrm{CH}_{4}$ emission with a contribution of $96.3 \%$ (Table 1). Our results contrast with those of Liu et al. ${ }^{18}$, who reported such conversion significantly reduced $\mathrm{CH}_{4}$ and $\mathrm{N}_{2} \mathrm{O}$ emissions by $48 \%$ and $56 \%$, respectively. Annual $\mathrm{CH}_{4}$ emission in Liu's ponds (equipped with aerators and classified as semi-intensive, see below) was just $32.6 \mathrm{~kg} \mathrm{CH}_{4} \mathrm{ha}^{-}$

${ }^{1}$ despite the much greater feeding rate and higher sediment DOC concentration compared to test extensive ponds. Hence, substrate availability was not the limiting factor for $\mathrm{CH}_{4}$ emissions in feeding aquaculture systems, while oxygen exposure by aeration was the key factor affecting $\mathrm{CH}_{4}$ emissions. Our results highlight that GHG emissions clearly differ from one aquaculture system to another, greatly depending on the intensity of operational management. This observation illustrates the potential for mitigating the effects of future paddy field conversion through careful management.

\section{Global $\mathrm{CH}_{4}$ and $\mathrm{N}_{2} \mathrm{O}$ budgets of freshwater aquaculture}

Here, we classified aquaculture into four systems: rice-fish, extensive, semi-intensive and intensive 
based on local conditions and aquaculture facilities especially whether aerators are used or not (see Methods). We compiled a worldwide database of $\mathrm{CH}_{4}$ and/or $\mathrm{N}_{2} \mathrm{O}$ emissions that were measured in 45 inland freshwater aquaculture systems during 2003-2015 (Supplementary Table 5). Land-use and production statistics were also compiled for different aquaculture systems of top 21 freshwater aquaculture producers (Supplementary Table 6); however, data from extensive and semi-intensive systems were pooled because of unavailability of aerator-use data for separate classification. In 2014, the top 21 producers contributed $97.5 \%$ of global freshwater aquaculture volume ${ }^{1}$.

The synthesized data show that $\mathrm{CH}_{4}$ fluxes ranged from -0.03 to $37.0 \mathrm{mg} \mathrm{CH}_{4} \mathrm{~m}^{-2} \mathrm{~h}^{-1}$ in rice-fish, extensive, and semi-intensive systems. Mean $\mathrm{CH}_{4}$ flux in rice-fish system was the highest at $12.6 \pm 3.9 \mathrm{mg} \mathrm{CH}_{4} \mathrm{~m}^{-2} \mathrm{~h}^{-1}$, followed by extensive and semi-intensive systems (Fig. 2a). The absence of $\mathrm{CH}_{4}$ flux in intensive systems can be attributed to a combination of continuous aeration, water exchange and a lack of habitats for methanogens ${ }^{4}$. The rice-fish system also had the highest mean $\mathrm{N}_{2} \mathrm{O}$ flux followed by semi-intensive and extensive systems $(28.4 \pm 9.8$ and $7.56 \pm 3.02 \mu \mathrm{g}$ $\mathrm{N}_{2} \mathrm{O} \mathrm{m} \mathrm{m}^{-2} \mathrm{~h}^{-1}$, respectively; Fig. 2b). The $\mathrm{EF}_{\mathrm{N}}$ and yield-scale $\mathrm{N}_{2} \mathrm{O} E F\left(E F_{Y}\right)$ in intensive system were $1.16 \pm 0.18 \%$ and $2.48 \pm 0.42 \mathrm{~g} \mathrm{~N}_{2} \mathrm{O} \mathrm{kg}{ }^{-1}$ yield, respectively, which were significantly higher than the corresponding values in extensive $\left(0.24 \pm 0.10 \%\right.$ and $0.66 \pm 0.22 \mathrm{~g} \mathrm{~N}_{2} \mathrm{O} \mathrm{kg}{ }^{-1}$ yield $)$ and semi-intensive $\left(0.35 \pm 0.16 \%\right.$ and $0.88 \pm 0.41 \mathrm{~g} \mathrm{~N}_{2} \mathrm{O} \mathrm{kg}{ }^{-1}$ yield $)$ systems. The $\mathrm{EF}_{\mathrm{Y}}$ in intensive systems was close to the IPCC default $\mathrm{EF}_{\mathrm{Y}}\left(2.66 \mathrm{~g} \mathrm{~N}_{2} \mathrm{O} \mathrm{kg}\right.$-1 yield) that is widely used in model estimate for aquaculture ${ }^{10,21}$, but was 2.75 - and 1.82 -fold greater than that for extensive and semi-intensive systems, respectively. Considering the large volume of extensive and semi-intensive aquaculture (Supplementary Table 6), previous estimates ${ }^{10,14}$ of global aquaculture $\mathrm{N}_{2} \mathrm{O}$ emission may have been overestimated because of the higher default $\mathrm{EF}_{\mathrm{Y}}$ mentioned above.

The estimated $\mathrm{CH}_{4}$ and $\mathrm{N}_{2} \mathrm{O}$ emissions from the top 21 producers in 2014 were $6.04 \pm 1.17 \mathrm{Tg}$ 
$\mathrm{CH}_{4}$ and $36.7 \pm 6.1 \mathrm{Gg} \mathrm{N} \mathrm{N}_{2} \mathrm{O}$, respectively (Table 2), which accounted for $1.82 \%$ and $0.34 \%$ of global anthropogenic $\mathrm{CH}_{4}$ and $\mathrm{N}_{2} \mathrm{O}$ emissions, respectively. Methane was a key contributor (94.6\%; Fig. 2e) to GWP in freshwater aquaculture, of which $1.19 \pm 0.27 \mathrm{Tg} \mathrm{CH}_{4}$ was emitted from rice-fish system and $4.85 \pm 1.04 \mathrm{Tg} \mathrm{CH}_{4}$ from extensive plus semi-intensive systems. To our knowledge, this is the first global estimate of $\mathrm{CH}_{4}$ emission from freshwater aquaculture. Our estimated total $\mathrm{N}_{2} \mathrm{O}$ emission was much lower than the previous estimates of $90 \mathrm{Gg} \mathrm{N}_{2} \mathrm{O}$ (ref. 14) and $146 \mathrm{Gg} \mathrm{N}_{2} \mathrm{O}$ (ref. 10) of global aquaculture. Extensive plus semi-intensive systems contributed $87.0 \%$ of global volume of freshwater aquaculture, meanwhile, were the largest $\mathrm{CH}_{4}$ and $\mathrm{N}_{2} \mathrm{O}$ emitter $(80.3 \%$ and $45.2 \%$, respectively) from this sector. Intensive systems accounted for $8.89 \%$ of the production, $27.0 \%$ of total $\mathrm{N}_{2} \mathrm{O}$ emissions but negligible $\mathrm{CH}_{4}$ emissions. Rice-fish systems represented only $4.30 \%$ of aquaculture volume, yet they accounted for $19.7 \%$ and $27.8 \%$ of $\mathrm{CH}_{4}$ and $\mathrm{N}_{2} \mathrm{O}$ budgets, respectively.

The greenhouse gas intensity (GHGI, GWP/yield) was $3.59 \pm 0.74 \mathrm{~kg} \mathrm{CO}_{2} \mathrm{eq} \mathrm{kg}^{-1}$ yield in extensive plus semi-intensive systems, which was 4.46 -fold greater than that in intensive systems $\left(0.66 \pm 0.11 \mathrm{~kg} \mathrm{CO}_{2}\right.$ eq $\mathrm{kg}^{-1}$ yield; Fig. $\left.2 \mathrm{f}\right)$. Therefore, if half of the current productions from extensive plus semi-intensive systems $(19.5 \mathrm{Mt})$ are replaced by intensive systems, the $\mathrm{GWP}$ of $\mathrm{CH}_{4}$ and $\mathrm{N}_{2} \mathrm{O}$ emissions from freshwater aquaculture (excluding rice-fish) will be reduced by $40.1 \%$ from $143 \mathrm{Tg} \mathrm{CO}_{2}$ eq to $85.6 \mathrm{Tg} \mathrm{CO}_{2}$ eq.

China has emerged as the world's largest freshwater aquaculture emitter of $\mathrm{CH}_{4}(4.10 \pm 0.10 \mathrm{Tg}$ $\left.\mathrm{yr}^{-1}\right)$ and $\mathrm{N}_{2} \mathrm{O}\left(22.8 \pm 7.1 \mathrm{Gg} \mathrm{yr}^{-1}\right)$, contributing $68.0 \%$ and $62.1 \%$ of global budgets from the sector, respectively. In China, $\mathrm{CH}_{4}$ emissions from freshwater aquaculture with $7.57 \times 10^{6}$ ha equates to $36.5 \%$ of total $\mathrm{CH}_{4}$ emissions from paddy fields, natural wetlands and lakes $\left(11.3 \mathrm{Tg} \mathrm{CH}_{4} \mathrm{yr}^{-1}\right.$; $\mathrm{ref}$. 28). Since $83.0 \%$ of Chinese freshwater aquaculture $\mathrm{CH}_{4}$ emissions originate from extensive plus 
semi-intensive systems, a substantial reduction in emissions could be achieved through improved management practices, such as installing more efficient aerators in earthen ponds and implementing optimized feeding strategies for reducing feed waste.

In conclusion, the conversion of paddy fields to extensive crab aquaculture ponds sharply increased GWP, primarily through a drastic increase in $\mathrm{CH}_{4}$ release. Our findings emphasize the need to assess the climatic impacts of land-use shifts towards industrial-scale aquaculture. Methane is the most important GHG in freshwater aquaculture compared with $\mathrm{N}_{2} \mathrm{O}$, and it was primarily sourced from extensive plus semi-intensive systems. Our findings indicate that effective management of extensive and semi-intensive systems through conversion to intensive systems is urgently required to mitigate GHG emissions from the unprecedented growth of aquaculture.

\section{Methods}

Methods, including statements of data availability and any associated accession codes and references, are available in the online version of this paper.

\section{Data availability}

The authors declare that the data supporting the findings of this study are available within the article and its supplementary information files.

\section{References}

1. FAO. The State of World Fisheries and Aquaculture 2016. Contributing to food security and nutrition for all (FAO, 2016).

2. FAO. The State of World Fisheries and Aquaculture 2014. Opportunities and challenges (FAO, 
3. Ministry of Agriculture of the People's Republic of China (MoA) China Fisheries Yearbook 2013 (MoA of China, Chinese Agric. Press, 2014) (in Chinese).

4. $\mathrm{Hu}, \mathrm{Z}$. et al. Influence of carbohydrate addition on nitrogen transformations and greenhouse gas emissions of intensive aquaculture system. Sci. Total Environ. 470, 193-200 (2014).

5. Naylor, R. L. et al. Effect of aquaculture on world fish supplies. Nature 405, 1017-1024 (2000).

6. Cao, L. et al. China's aquaculture and the word's wild fisheries. Science 347, 133-135 (2015).

7. Boyd, C. E., Wood, C. W., Chaney, P. L. \& Queiroz, J. F. Role of aquaculture pond sediments in sequestration of annual global carbon emissions. Environ. Pollut. 158, 2537-2540 (2010).

8. Chatvijitkul, S., Boyd, C. E., Davis, D. A. \& McNevin, A. A. Pollution potential indicators for feed-based fish and shrimp culture. Aquaculture 477, 43-49 (2017).

9. Hargreaves, J. A. Nitrogen biogeochemistry of aquaculture ponds. Aquaculture 166, 181-212 (1998).

10. Hu, Z., Lee, J. W., Chandran, K., Kim, S. \& Khanal, S. K. Nitrous oxide $\left(\mathrm{N}_{2} \mathrm{O}\right)$ emission from aquaculture: a review. Environ. Sci. Technol. 46, 6470-6480 (2012).

11. Boyd, C. E. \& Tucker, C. S. Handbook for Aquaculture Water Quality (Craftmaster Printers, 2014).

12. Alltech. 2017 Alltech Global Feed Survey (Alltech, 2017).

13. Green, B. W. in Feed and Feeding Practices in Aquaculture (ed. Davis, A. D.) 27-52 (Woodhead Publishing, 2015).

14. Williams, J. \& Crutzen, P. Nitrous oxide from aquaculture. Nat. Geosci. 3, 143-143 (2010).

15. Ahn, J. H. et al. $\mathrm{N}_{2} \mathrm{O}$ emissions from activated sludge processes, 2008-2009: results of a national monitoring survey in the United States. Environ. Sci. Technol. 44, 4505-4511 (2010). 
16. Paudel, S. R. et al. Effects of temperature on nitrous oxide $\left(\mathrm{N}_{2} \mathrm{O}\right)$ emission from intensive aquaculture system. Sci. Total Environ. 518-519, 16-23 (2015).

17. Hu Z. A comparison of methane and nitrous oxide emissions between paddy fields and crab/fish farming wetlands in southeast China. (Doctoral thesis, Nanjing Agri. Univ., 2015) (in Chinese).

18. Liu, S. et al. Methane and nitrous oxide emissions reduced following conversion of rice paddies to inland crab-fish aquaculture in southeast China. Environ. Sci. Technol. 50, 633-642 (2016).

19. Holgerson, M. A. \& Raymond, P. A. Large contribution to inland water $\mathrm{CO}_{2}$ and $\mathrm{CH}_{4}$ emissions from very small ponds. Nat. Geosci. 9, 222-226 (2016).

20. Cai, Z., Tsuruta, H. \& Minami, K. Methane emission from rice fields in China: measurements and influencing factors. J. Geophys. Res. Atmos. 105, 17231-17242 (2000).

21. IPCC. 2013 Supplement to the 2006 IPCC Guidelines for National Greenhouse Gas Inventories: Wetlands (eds Hiraishi, T. et al.) (IPCC, 2014).

22. Burford, M. A. \& Williams, K. C. The fate of nitrogenous waste from shrimp feeding. Aquaculture 198, 79-93 (2001).

23. IPCC. 2006 IPCC Guidelines for National Greenhouse Gas Inventories Vol. 4 (eds Eggleston, H. S., Buendia, L., Miwa, K., Ngara, T. \& Tanabe, K.) Ch. 11 (IGES, 2006).

24. Freeman, C., Lock, M. A., Reynolds, B. \& Hudson, J. A. Nitrous oxide emissions and the use of wetlands for water quality amelioration. Environ. Sci. Technol. 50, 2438-2440 (1997).

25. Dobbie, K. E. \& Smith, K. A. Impact of different forms of $\mathrm{N}$ fertilizer on $\mathrm{N}_{2} \mathrm{O}$ emissions from intensive grassland. Nutr. Cycl. Agroecosys. 67, 37-46 (2003).

26. Miller, M. N. et al. Crop residue influence on denitrification, $\mathrm{N}_{2} \mathrm{O}$ emissions and denitrifier community abundance in soil. Soil Biol. Biochem. 40, 2553-2562 (2008).

27. Ma, Y. et al. Net global warming potential and greenhouse gas intensity of annual rice-wheat 
rotations with integrated soil-crop system management. Agric. Ecosyst. Environ. 164, 209-219 (2013).28. Chen, H. et al. Methane emissions from rice paddies natural wetlands, lakes in China: synthesis new estimate. Global Change Biol. 19, 19-32 (2013).

29. Xie, Z. et al. $\mathrm{CO}_{2}$ mitigation potential in farmland of China by altering current organic matter amendment pattern. Sci. China Earth Sci. 53, 1351-1357 (2010).

30. Frei, M. et al. Methane emissions and related physicochemical soil and water parameters in rice-fish systems in Bangladesh. Agric. Ecosyst. Environ. 120, 391-398 (2007).

\section{Additional information}

Correspondence and requests for materials should be addressed to W.D. or C.F.

\section{Acknowledgements}

This work was supported by grants from the Chinese Academy of Sciences (XDB15020100), the Natural Science Foundation of Jiangsu Province (BK20151056) and China (41501274, 41471077), and the Special Fund for Forest Scientific Research in Public Welfare (201404210). H.K. is grateful to NRF (2016R1D1A1A02937049) and KFS (2017096A001719BB01).

\section{Author contributions}

W.D., J.Y., and D.L. designed the study; J.X. led the GHG fluxes and auxiliary measurements with the support of T.H., S.K., and Y.L. Site selection and set-up was carried out by J.Y., and D.L. H.K. and C.F. were the key international collaborators during this research. The manuscript was drafted by J.Y., H.K., W.D. and C.F with all authors contributing to the final version. 
269 The authors declare no competing financial interests. 
Site description Field experiments were carried out in a conventional paddy field (PF) and three adjacent crab ponds in the Tai Lake basin $\left(31^{\circ} 02^{\prime} \mathrm{N}, 120^{\circ} 25^{\prime} \mathrm{E}\right)$, Suzhou City, Jiangsu Provence, China (Supplementary Fig. 1). This region is characterized by a subtropical monsoon climate with the long-term (1981-2010) mean annual air temperature of $16.5^{\circ} \mathrm{C}$ and precipitation of $1176 \mathrm{~mm}$ (http://cdc.nmic.cn/home.do). Paddy fields accounted for $65 \%$ of total cropland in this region, however, they are being rapidly converted to aquaculture ponds due to the greater economic benefits from the latter since 1980s (ref. 31).

Soil was developed from alluvial sediments of the Yangtze River, and classified as stagnic Anthrosols based on the USDA soil taxonomy. The surface soil $(0-20 \mathrm{~cm})$ had a $\mathrm{pH}\left(\mathrm{H}_{2} \mathrm{O}\right)$ of 5.95, bulk density of $1.25 \mathrm{~g} \mathrm{~cm}^{-3}$ and a loam texture with $40 \%$ sand, $34 \%$ silt and $26 \%$ clay, and contained $20.3 \mathrm{~g} \mathrm{~kg}^{-1}$ organic $\mathrm{C}$ and $1.81 \mathrm{~g} \mathrm{~N} \mathrm{~kg}^{-1}$ total $\mathrm{N}$. Three neighboring aquaculture ponds for Chinese mitten crab (Eriocheir sinensis) cultivation were converted from paddy fields in 2001.

\section{Experimental design and field management Four independent $3 \times 8 \mathrm{~m}^{2}$ plots were established in} PF in November 2012. Winter wheat (Triticum aestivum L., Yangfumai 4) and summer rice (Oryza sativa L., Wuyunjing 23) was rotated during the period from November 2012 to May 2014. During wheat season, urea was applied at the rate of $150 \mathrm{~kg} \mathrm{~N} \mathrm{ha}^{-1}$, with basal and supplemental fertilization ratio of $40 \%: 60 \%$. During rice season, urea was applied at the rate of $280 \mathrm{~kg} \mathrm{~N} \mathrm{ha}{ }^{-1}$, with the basal and supplemental fertilizer ratio of 50\%:50\%. Calcium superphosphate (40 and 125 $\mathrm{kg} \mathrm{P}_{2} \mathrm{O}_{5} \mathrm{ha}^{-1}$ for wheat and rice, respectively) and potassium sulfate (60 and $125 \mathrm{~kg} \mathrm{~K}_{2} \mathrm{O} \mathrm{ha}^{-1}$ for wheat and rice, respectively) were applied as basal fertilizers (Supplementary Table 2). The row distance was $25 \mathrm{~cm}$ for rice and wheat, and the hill distance was $15 \mathrm{~cm}$ for rice. No irrigation was 
performed during wheat season, while rice was managed under a typical water regime mode of

flooding-midseason drainage-reflooding-moist irrigation (F-D-F-M). Crop grain and straw were harvested and oven dried at $60^{\circ} \mathrm{C}$ until a constant weight.

Parallel field experiments were conducted in three neighboring crab ponds with different size (CP1, 1.71 ha; CP2, 0.71 ha; CP3, 0.09 ha), from March 2013 to March 2014. Monoculture of Chinese mitten crab was employed at the same stocking density of 15000 ind ha ${ }^{-1}$ for each pond. The submerged western waterweed (Elodea nuttallii) naturally vegetated in ponds and provided molting shelters and foods for crabs. Feeds and fertilizers were applied at the same rates in each pond. Snails (Bellamya quadrata) were introduced into the ponds twice at the rates of 600 and 400 $\mathrm{kg} \mathrm{ha}^{-1}$ on April 4 and June 20, respectively, to filter feed residue and provide supplementary foods for crabs (Supplementary Tables 2 and 3). Crabs were fed with commercial feed pellets $(2050 \mathrm{~kg}$ $\mathrm{ha}^{-1}$ ) (Purina Co. Ltd., Jiaxing, China), trash fish $\left(1250 \mathrm{~kg} \mathrm{ha}^{-1}\right)$ and corn seeds $\left(1150 \mathrm{~kg} \mathrm{ha}^{-1}\right)$, twice per day on 9:00 a.m. and 17:00 p.m. until the crabs were harvested. In order to stimulate phytoplankton and waterweed production, cake manure (residue of de-oiled oil seeds) at $40 \mathrm{~kg} \mathrm{ha}^{-1}$ was applied as basal fertilizer while urea, compound fertilizer and calcium superphosphate were applied at the rate of 130,100 and $200 \mathrm{~kg} \mathrm{ha}^{-1}$, respectively, with four splits of $25 \%: 25 \%: 25 \%: 25 \%$ on March 29, June 5, August 12 and September 27. Annual inputs of $\mathrm{C}$ and $\mathrm{N}$ to crab ponds were 1.20 $\mathrm{Mg} \mathrm{C} \mathrm{ha}^{-1}$ and $244 \mathrm{~kg} \mathrm{~N} \mathrm{ha}^{-1}$, respectively. Water was constantly maintained all-year round, while the water depth differed between ponds. Crab harvest started from 1 to 30 October 2013, depending on crab maturity. Crab yield was expressed as fresh weight (Supplementary Table 4). Details management practices in the two systems are shown in Supplementary Table 3.

Measurement of GHG fluxes Wooden boardwalks were installed in each plot to facilitate 
collecting gas samples and measuring the auxiliary parameters (Supplementary Fig. 2). The static closed chamber technique was used to measure GHG fluxes; in PF, PVC chamber collars $(50 \mathrm{~cm} \times$ $50 \mathrm{~cm} \times 20 \mathrm{~cm}$ ) with a water-filled channel were inserted into the soil at a depth of $15 \mathrm{~cm}$. In crab ponds, a specially designed system, which included four stainless steel pegs for fixing the system and two adjustable crossbars for elevating or lowering the chamber collars with the fluctuation of water level, were installed along the boardwalks to minimize water wave impact on gas sampling.

Three PVC chamber collars were placed on the crossbars in each pond. If necessary, the crossbars together with the chamber collars were adjusted to the best position one day before sampling. The transparent Plexiglass chambers $(50 \mathrm{~cm} \times 50 \mathrm{~cm} \times 15 \mathrm{~cm})$ in crab ponds and the stainless steel chambers $(50 \mathrm{~cm} \times 50 \mathrm{~cm} \times 50 \mathrm{~cm})$ insulated with white foam in PF were used. See Yuan et al. ${ }^{32}$ for further detailed information of the devices.

The GHG fluxes were measured twice weekly in crab ponds during crab production period from March to October and weekly during period without crab production from November to February (Supplementary Fig. 3). In PF, GHG fluxes were measured twice weekly from April to November and weekly from December to March. Gas sampling was conducted at 08:00-10:00 local time to minimize diurnal variation in the flux pattern. During sampling, the chamber was fitted into the water trough of the chamber collars. Each time, four gas samples of the chamber headspace were drawn using a 50-mL syringes at $0,10,20$, and 30 min after closure and injected into $22-\mathrm{mL}$ pre-evacuated glass vials. Air temperature inside the chamber was simultaneously measured with a mercury thermometer. Concentrations of $\mathrm{CH}_{4}, \mathrm{~N}_{2} \mathrm{O}$ and $\mathrm{CO}_{2}$ were determined by a gas chromatograph (Agilent 7890, Santa Clara, CA, USA) equipped with a flame ionization detector for $\mathrm{CO}_{2}$ and $\mathrm{CH}_{4}$ and a ${ }^{63} \mathrm{Ni}$ electron capture detector for $\mathrm{N}_{2} \mathrm{O}$. The gas standards were provided by the National Research Center for Certified Reference Materials, Beijing, China. The precision for GHG 
concentrations was $\pm 0.5 \%$ based on repeated measurements of gas standards. The GHG fluxes were calculated using a linear least squares fit to the four points in the time series of concentration for each plot. Data were omitted if the slope of the linear fitting had $R^{2}<0.90$. Since the opaque chambers were used in $\mathrm{PF}$, the measured $\mathrm{CO}_{2}$ fluxes were ecosystem respiration $(R e)$; in contrast, $\mathrm{CO}_{2}$ fluxes in crab ponds measured by transparent chambers were net ecosystem exchange ${ }^{32}$. The dataset of GHG fluxes were supplied as Supplementary Table 7.

Annual or seasonal cumulative $\mathrm{CH}_{4}\left(\mathrm{~kg} \mathrm{CH}_{4} \mathrm{ha}^{-1}\right), \mathrm{N}_{2} \mathrm{O}\left(\mathrm{kg} \mathrm{N}_{2} \mathrm{O}\right.$ ha $\left.{ }^{-1}\right)$ and $\mathrm{CO}_{2}\left(\mathrm{~kg} \mathrm{CO}_{2} \mathrm{ha}^{-1}\right)$ emissions $(E)$ were calculated using the following equation:

$E=\sum_{i=1}^{n}\left(f_{i}+f_{i+1}\right) / 2 \times\left(t_{i+1}-t_{i}\right) \times 24 \times 10^{-2}$

where $f$ represents the flux of $\mathrm{CH}_{4}\left(\mathrm{mg} \mathrm{CH}_{4} \mathrm{~m}^{-2} \mathrm{~h}^{-1}\right)$ or $\mathrm{N}_{2} \mathrm{O}\left(\mathrm{mg} \mathrm{N}_{2} \mathrm{O} \mathrm{m}^{-2} \mathrm{~h}^{-1}\right)$ or $\mathrm{CO}_{2}\left(\mathrm{mg} \mathrm{CO}_{2} \mathrm{~m}^{-2}\right.$ $\left.\mathrm{h}^{-1}\right) ; i$ is the $i$ th measurement; $\left(t_{i+1}-t_{\mathrm{i}}\right)$ is the days between two adjacent measurements; and $24 \times$ $10^{-2}$ was used for unit conversion.

Auxiliary measurements Redox potential of the intact soil and sediment at $10 \mathrm{~cm}$ depth was measured in situ using a PHB-6 pH/mV meter (Jiaoyuan Instrument, Yancheng, China). The soil of PF or sediment of ponds at $10 \mathrm{~cm}$ depth was collected weekly using a Russian corer for mineral $\mathrm{N}$ and dissolved organic $\mathrm{C}$ measuring. The $\mathrm{NH}_{4}{ }^{+}$and $\mathrm{NO}_{3}{ }^{-}$were extracted with $2 \mathrm{M} \mathrm{KCl}$ solution (shaken for $1 \mathrm{~h}$ and then filtered); extracts were filtered and analyzed on a continuous-flow analyzer (SAN++, Skalar, Breda, the Netherlands). Dissolved organic C was extracted with deionized water (shaken for $30 \mathrm{~min}$ at $25^{\circ} \mathrm{C}$, centrifuged for $25 \mathrm{~min}$ at $4000 \mathrm{rpm}$, and filtered through $0.45-\mu \mathrm{m}$ membrane filter) and measured on a TOC analyzer (TOC Vcph, Shimadzu, Kyoto, Japan). Soil organic $\mathrm{C}$ (SOC) and total $\mathrm{N}$ contents were determined by the wet-oxidation redox method and the 
Kjeldahl procedure, respectively ${ }^{33}$.

Estimates of SOC change in paddy field and GWP The SOC change $(\delta \mathrm{SOC})$ in PF was estimated from the net ecosystem $\mathrm{C}$ balance (NECB) using a coefficient of 0.213 for paddy soils in this study $^{29}$, namely, the conversion rate of organic $\mathrm{C}$ gain to SOC is $213 \mathrm{~g} \mathrm{C} \mathrm{kg}^{-1}$. The NECB of the short-plant croplands was calculated according to Ma et al. ${ }^{27}$ :

$\mathrm{NECB}=\mathrm{GPP}-\mathrm{Re}-$ Harvest $-\mathrm{CH}_{4}+$ Manure

where GPP (gross primary production) is inferred from NPP (net primary production) via the NPP/GPP ratio of 0.58 in this region deduced by Zhang et al. ${ }^{34} ; R e, \mathrm{CH}_{4}$ and manure are the $\mathrm{C}$ exchange through ecosystem respiration, $\mathrm{CH}_{4}$ emission, and manure application, respectively; Harvest is the $\mathrm{C}$ of removed straw and grain, which was calculated based on biomass yields, and $\mathrm{C}$ and $\mathrm{N}$ contents in straw and grain (Supplementary Table 4). The NPP includes net primary productions of grain, straw, root, litter and rhizodeposit, according to Ma et al. ${ }^{27}$.

The GWP $\left(\mathrm{Mg} \mathrm{CO}_{2}\right.$ eq ha $\left.{ }^{-1}\right)$ in PF is calculated by the following equation ${ }^{35}$ :

$\mathrm{GWP}=28 \times \mathrm{CH}_{4}+265 \times \mathrm{N}_{2} \mathrm{O}-44 / 12 \times \delta \mathrm{SOC}$

and for crab ponds:

$\mathrm{GWP}=28 \times \mathrm{CH}_{4}+265 \times \mathrm{N}_{2} \mathrm{O}+1 \times \mathrm{CO}_{2}$

where $\mathrm{CH}_{4}, \mathrm{~N}_{2} \mathrm{O}$ and $\mathrm{CO}_{2}$ denote annual emissions of $\mathrm{CH}_{4}\left(\mathrm{Mg} \mathrm{CH}_{4} \mathrm{ha}^{-1}\right), \mathrm{N}_{2} \mathrm{O}\left(\mathrm{Mg} \mathrm{N}_{2} \mathrm{O}\right.$ ha $\left.{ }^{-1}\right)$ and $\mathrm{CO}_{2}\left(\mathrm{Mg} \mathrm{CO}_{2} \mathrm{ha}^{-1}\right)$, respectively.

Data collection and classification of global freshwater aquaculture As mentioned above, there are large uncertainties in previous model estimates of global aquaculture $\mathrm{N}_{2} \mathrm{O}$ emissions by using EFs of applied $\mathrm{N}$ and fish yields: First, the $\mathrm{N}_{2} \mathrm{O}$ EFs are highly dependent on management levels in the aquaculture system. For example, yield-scale $\mathrm{N}_{2} \mathrm{O}$ EF $\left(\mathrm{EF}_{\mathrm{Y}}\right)$ of carp was $1.07 \mathrm{~g} \mathrm{~N}_{2} \mathrm{O} \mathrm{kg}$ yield $^{-1}$ 
in an intensive rearing system ${ }^{16}$ but was only $0.28 \mathrm{~g} \mathrm{~N}_{2} \mathrm{O} \mathrm{kg}$ yield in a semi-intensive earthen pond $^{17}$; Secondly, the $\mathrm{EF}_{\mathrm{Y}}$ can be biased by the major yield difference between species. For instance, although the direct $\mathrm{N}_{2} \mathrm{O}$ emission rates in two adjacent semi-intensive aquaculture ponds were comparable, the $\mathrm{EF}_{\mathrm{Y}}$ measured in crab ponds was 8.11-fold greater than that in carp ponds due to the magnitude difference in yields ${ }^{17,18}$.

Here, we compiled a worldwide database of GHG emissions measured in the inland freshwater aquaculture systems (Supplementary Table 5). We identified potential published studies for inclusion in the database using Web of Science with the keywords 'greenhouse gases or $\mathrm{CH}_{4}$ or $\mathrm{N}_{2} \mathrm{O}$ ' and 'aquaculture or fish farming or rice fish or aquaponics'. Twenty-four studies fell within the inland freshwater aquaculture and met the following criteria: (i) field measurement of $\mathrm{CH}_{4}$ and/or $\mathrm{N}_{2} \mathrm{O}$ emissions was carried out on a per hectare or per fish yield basis; (ii) type of aquaculture system with or without aerator use was reported; (iii) the $\mathrm{N}$ input and yield in intensive systems were listed (see below). The dataset include $45 \mathrm{CH}_{4}$ and/or $\mathrm{N}_{2} \mathrm{O}$ emission measurements across 19 sites between 2003 and 2015 .

Generally, the aquaculture systems are classified based on production per unit volume or per unit $\operatorname{area}^{36}$; however, when estimating the regional or global GHG emissions, such classification might be unfit due to lack of the available production data counted by volume or area and deficiency of the cross-species classification criteria for big differences in production performance between culture species. Here, we classified four systems: rice-fish, extensive, semi-intensive and intensive based on the local conditions and aquaculture facilities especially aerator use or not. Actually, the stocking density and production are associated with investment on infrastructure especially aeration equipment ${ }^{36}$, because the dissolved oxygen in fish ponds should be maintained $>5.0 \mathrm{mg} \mathrm{L}^{-1}$, theoretically ${ }^{37}$. 
- Rice-fish systems include integrated rice field or rice field-pond complex and are used to produce fish and other aquatic animals.

- Extensive aquaculture systems involve excavated earthen ponds, irrigation canals and ditches, small lakes and reservoirs used for fish farming. Extensive systems have low stocking density, with natural productivity or limited supplemental feeds and no aerator system.

- Semi-intensive aquaculture systems include excavated earthen ponds, irrigation canals and ditches, small lakes and reservoirs, have higher stocking densities than extensive systems, and are equipped with aerators and managed with artificial feeds and intermittent aeration.

- Intensive aquaculture systems, which utilize man-made rearing units such as concrete/canvas tanks, raceways recirculating systems, have high stocking rates and complete diet management, intensive and continuous aeration, and frequent or continuous water exchange. The cage and pen culture performed in open water bodies like rivers, lakes and reservoirs are also classified as intensive aquaculture because of the high stocking rates and sufficient dissolved oxygen supply from the constant water exchange.

Global inventory of the land use and production statistics are also compiled in different aquaculture systems of the major freshwater aquaculture producers (Supplementary Table 6), however, data of extensive and semi-intensive systems were pooled because of lack of aerator use data to classify each other. Data were derived from the official fisheries statistics for 2014. In case 2014 data were not available, the most recent data were used. If the national official statistical data were not available, the FAO estimate (National Aquaculture Sector Overview) or private survey data were used. Further details on the statistics used are provided in the Supplementary materials.

Estimation of global $\mathbf{C H}_{4}$ and $\mathrm{N}_{2} \mathrm{O}$ budgets We estimated $\mathrm{N}_{2} \mathrm{O}$ emissions from intensive systems 
by multiplying $\mathrm{EF}_{\mathrm{Y}}$ by production. Methane emission from intensive systems was recognized as negligible because the aerobic condition limited $\mathrm{CH}_{4}$ production in such systems ${ }^{4}$. While $\mathrm{CH}_{4}$ and $\mathrm{N}_{2} \mathrm{O}$ emissions from rice-fish, extensive, and semi-intensive aquaculture systems were estimated by multiplying mean emission rates by area, because (i) the yield $\mathrm{EF}$ for $\mathrm{CH}_{4}$ was generally unavailable in literature; and (ii) the $\mathrm{EF}_{\mathrm{Y}}$ would be biased by the huge yield difference between species in extensive and semi-intensive systems. Additionally, when estimating $\mathrm{CH}_{4}$ emission from rice-fish systems, the $\mathrm{CH}_{4}$ fluxes $\left(32-37 \mathrm{mg} \mathrm{CH}_{4} \mathrm{~m}^{-2} \mathrm{~h}^{-1}\right)$ measured in Bangladesh ${ }^{30}$ were excluded from mean emission rates, because of the extremely high emission rates and relatively small area of rice-fish in Bangladesh ( $\sim 3.97 \%$ of global rice-fish area).

It should be noted that our preliminary estimates possess some uncertainties. First, field measurements of $\mathrm{CH}_{4}$ and $\mathrm{N}_{2} \mathrm{O}$ fluxes were mainly conducted during the feeding period, may result in overestimation of $\mathrm{CH}_{4}$ and $\mathrm{N}_{2} \mathrm{O}$ emissions; secondly, only averaged $\mathrm{CH}_{4}$ and $\mathrm{N}_{2} \mathrm{O}$ fluxes in extensive and semi-intensive systems were set up due to the absence of detailed aquaculture facilities data; thirdly, there was no detailed information relative to land use and production in aquaculture in many main producers (e.g. Brazil, Nigeria). More field measurements along with detailed national aquaculture information in those countries are required to obtain more reliable estimates. Moreover, our estimates only focused on the direct $\mathrm{CH}_{4}$ and $\mathrm{N}_{2} \mathrm{O}$ emissions, however, GHG emission from adjacent water bodies can also be enhanced by the nutrients loading caused by water exchange in some aquaculture systems (especially intensive systems). Hence, these potential indirect emissions should be considered in future estimates.

\section{References}

31. Zhang, F., Xing, Y., Pu, L. \& Peng, B. Study on the eco-environmental effect of land use change 
in Suzhou. Res. Soil Water Conserv. 16, 98-103 (2009) (in Chinese).

454

455

456

457

458

459

460

461

462

463

464

465

32. Yuan, J. et al. Exotic Spartina alterniflora invasion alters ecosystem-atmosphere exchange of $\mathrm{CH}_{4}$ and $\mathrm{N}_{2} \mathrm{O}$ and carbon sequestration in a coastal salt marsh in China. Glob. Change Biol. 21, $1567-1580$ (2015).

33. Carter, M. R. Soil Sampling and Methods of Analysis (Lewis Publishers, 1993).

34. Zhang, Y., Xu, M., Chen, H. \& Adams, J. Global pattern of NPP to GPP ratio derived from MODIS data: effects of ecosystem type, geographical location and climate. Global Ecol. Biogeogr. 18, 280-290 (2009).

35. Ciais, P. et al. in Climate change 2013: The Physical Science Basis (eds Stocker T. F. et al.) Ch. 6, 465-570 (IPCC, Cambridge Univ. Press, 2014).

36. Lekang, O-I. Aquaculture engineering (John Wiley \& Sons, 2008).

37. Losordo, T. M., Masser, M. P \& Rakocy, J. Recirculating Aquaculture Tank Production Systems: Management of Recirculating Systems (SRAC Publication, 1998). 
Figure legends:

Figure 1. Annual $\mathrm{CH}_{4}, \mathrm{~N}_{2} \mathrm{O}$ and $\mathrm{CO}_{2}$ emissions from the paddy field (PF) and crab ponds (CP) during 2013-2014. a, $\mathrm{CH}_{4}, \mathbf{b}, \mathrm{N}_{2} \mathrm{O}, \mathbf{c}, \mathrm{CO}_{2}$. Vertical bars represent standard errors of the means ( $n$ $=4$ for $\mathrm{PF}$ and $n=3$ for crab ponds). Three crab ponds had different size and water depth (Supplementary Table 1). 'A', 'B', and 'C' denote significant differences between sites $(P<0.05$, ANOVA, Tukey's HSD test) during the entire year; 'a', 'b', and 'c' denote significant differences between crab ponds during the crab production period or during the period without crab production. $\mathrm{CO}_{2}$ release from PF was calculated from soil organic $\mathrm{C}$ change estimates using the net ecosystem C balance method.

Figure 2. Literature-sourced greenhouse gas emission factors of different aquaculture. a, mean $\mathrm{CH}_{4}$ emission rate, $\mathbf{b}$, mean $\mathrm{N}_{2} \mathrm{O}$ emission rate, $\mathbf{c}, \mathrm{N}_{2} \mathrm{O}$ emission factor of applied $\mathrm{N}\left(\mathrm{EF}_{\mathrm{N}}\right)$, d, yield based $\mathrm{N}_{2} \mathrm{O}$ emission $\left(\mathrm{EF}_{\mathrm{Y}}\right)$. Boundaries of the boxes indicate the first and third quartiles, line within the box and the white square represent the median and average, respectively. Whiskers mark the 10th and 90th percentiles, and the outliers are shown as dots. e, global warming potential (GWP), f, greenhouse gas intensity (GHGI, GWP/yield). Vertical bars represent standard errors of the means. Aquaculture systems are classified based on the local conditions and aquaculture facilities especially whether aerators were used or not. 

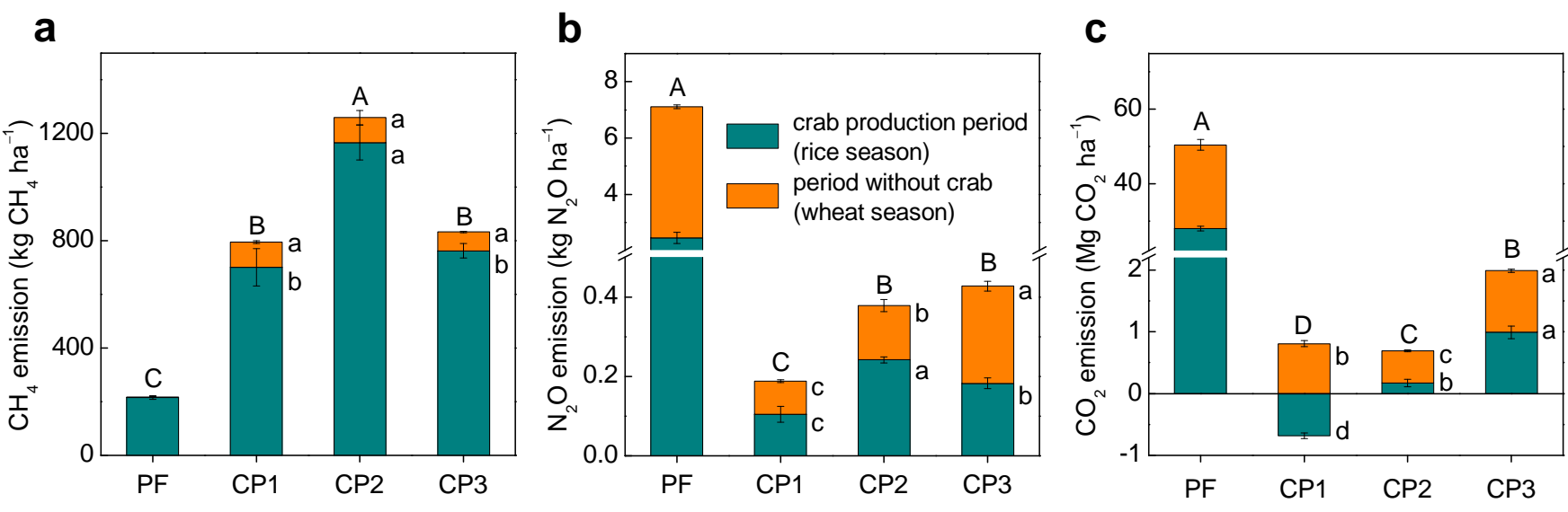


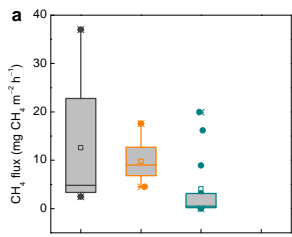

Rice-fish Extensive Semi-intensive Intensive

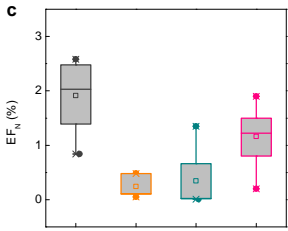

Rice-fish Extensive Semi-intensive Intensive

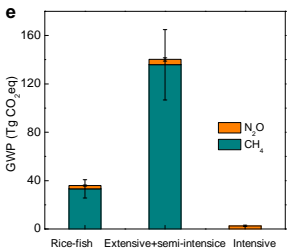

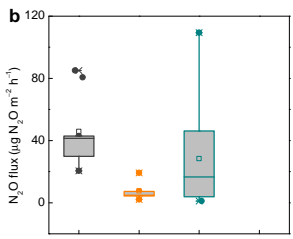

Rice-fish Extensive Semi-intensive Intensive

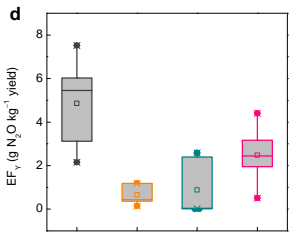

Rice-fish Extensive Semi-intensive Intensive

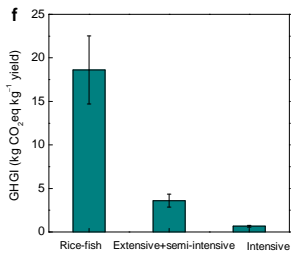


Table 1 Annual GHG emissions, net GWP and emission factors of $\mathrm{CH}_{4}$ and $\mathrm{N}_{2} \mathrm{O}$ in paddy field and crab ponds

\begin{tabular}{|c|c|c|c|c|c|c|c|c|c|c|}
\hline Systems & $\begin{array}{c}\mathrm{CH}_{4} \\
\left(\mathrm{~kg} \mathrm{CH}_{4}\right. \\
\left.\mathrm{ha}^{-1}\right)\end{array}$ & $\begin{array}{c}\mathrm{N}_{2} \mathrm{O} \\
\left(\mathrm{kg} \mathrm{N}_{2} \mathrm{O}\right. \\
\left.\mathrm{ha}^{-1}\right)\end{array}$ & $\begin{array}{c}\mathrm{CO}_{2} * \\
\left(\mathrm{Mg} \mathrm{CO}_{2}\right. \\
\left.\mathrm{ha}^{-1}\right)\end{array}$ & $\begin{array}{c}\text { C input } \dagger \\
(\mathrm{Mg} \mathrm{C} \\
\left.\mathrm{ha}^{-1}\right)\end{array}$ & $\begin{array}{c}\text { N input } † \\
(\mathrm{~kg} \mathrm{~N} \\
\left.\mathrm{ha}^{-1}\right)\end{array}$ & $\begin{array}{c}\delta \mathrm{SOC} \ddagger \\
(\mathrm{Mg} \mathrm{C} \\
\left.\mathrm{ha}^{-1}\right)\end{array}$ & $\begin{array}{c}\text { Net GWP§ } \\
\left(\mathrm{Mg} \mathrm{CO}_{2} \mathrm{eq}\right. \\
\left.\mathrm{ha}^{-1}\right)\end{array}$ & $\begin{array}{c}\mathrm{EF}_{\mathrm{C}} \dagger \dagger \\
(\%)\end{array}$ & $\begin{array}{c}\mathrm{EF}_{\mathrm{N}} \| \\
(\%)\end{array}$ & $\begin{array}{c}\mathrm{EF}_{\mathrm{Y}} \boldsymbol{I} \\
\left(\mathrm{g} \mathrm{N}_{2} \mathrm{O}\right. \\
\mathrm{kg}^{-1} \text { yield) }\end{array}$ \\
\hline Paddy field & $218 \pm 7 b$ & $7.11 \pm 0.23 \mathrm{a}$ & $50.6 \pm 0.9 a$ & - & 430 & $-0.04 \pm 0.05$ & $8.15 \pm 0.43 b$ & - & $1.05 \pm 0.03 a$ & $0.56 \pm 0.02 \mathrm{a}$ \\
\hline Crab ponds & $962 \pm 149 a$ & $0.33 \pm 0.07 b$ & $0.93 \pm 0.55 b$ & 1.20 & 244 & - & $28.0 \pm 4.1 \mathrm{a}$ & $60.0 \pm 9.3$ & $0.09 \pm 0.02 b$ & $0.30 \pm 0.07 b$ \\
\hline
\end{tabular}

* The value is ecosystem respiration in paddy field and net ecosystem $\mathrm{CO}_{2}$ exchange for crab ponds. $†$ Calculated by application rates and $\mathrm{C}$ and

$3 \mathrm{~N}$ contents of the fertilizers and feeds (see Supplementary Tables 2-4). $¥$ Estimated from the net ecosystem carbon balance (NECB) using a 4 coefficient of 0.213 for paddy soils ${ }^{29}$. § Net GWP $=28 \times \mathrm{CH}_{4}+265 \times \mathrm{N}_{2} \mathrm{O}-44 / 12 \times \delta$ SOC for paddy field, and net GWP $=$ $528 \times \mathrm{CH}_{4}+265 \times \mathrm{N}_{2} \mathrm{O}+1 \times \mathrm{CO}_{2}$ for crab ponds. †† The direct emission factor of $\mathrm{C}$ for $\mathrm{CH}_{4}\left(\mathrm{EF}_{\mathrm{C}}\right)$ is calculated by dividing annual $\mathrm{CH}_{4}$ emission by

6 total $\mathrm{C}$ input ${ }^{21}$. T The direct emission factor of $\mathrm{N}$ for $\mathrm{N}_{2} \mathrm{O}\left(\mathrm{EF}_{\mathrm{N}}\right)$ and yield-scaled emission factor for $\mathrm{N}_{2} \mathrm{O}\left(\mathrm{EF}_{\mathrm{Y}}\right)$ are calculated by dividing 7 annual $\mathrm{N}_{2} \mathrm{O}$ emission by total $\mathrm{N}$ input and grain/crab yield, respectively. Values are means \pm standard errors. 
8 Table 2 Direct $\mathrm{CH}_{4}\left(\mathrm{Gg} \mathrm{CH}_{4} \mathrm{yr}^{-1}\right)$ and $\mathrm{N}_{2} \mathrm{O}\left(\mathrm{Mg} \mathrm{N}_{2} \mathrm{O} \mathrm{yr}^{-1}\right)$ emissions from

9 different freshwater aquaculture systems in global top 21 producers in 2014

\begin{tabular}{|c|c|c|c|c|c|c|c|}
\hline \multirow[t]{2}{*}{ Country/region } & \multicolumn{2}{|c|}{$\begin{array}{l}\text { Rice-fish } \\
\text { systems* }\end{array}$} & \multicolumn{2}{|c|}{$\begin{array}{l}\text { Extensive plus } \\
\text { semi-intensive } \\
\text { systems* }\end{array}$} & \multirow{2}{*}{$\begin{array}{c}\text { Intensive } \\
\text { systems } \dagger \\
\mathrm{N}_{2} \mathrm{O}\end{array}$} & \multicolumn{2}{|c|}{ Total } \\
\hline & $\mathrm{CH}_{4}$ & $\mathrm{~N}_{2} \mathrm{O}$ & $\mathrm{CH}_{4}$ & $\mathrm{~N}_{2} \mathrm{O}$ & & $\mathrm{CH}_{4}$ & $\mathrm{~N}_{2} \mathrm{O}$ \\
\hline China & 696 & 5,988 & 3,408 & 11,653 & 5,152 & 3,524 & 22,793 \\
\hline India & 108 & 925 & 487 & 1,667 & - & 512 & 2,591 \\
\hline Indonesia & 66 & 571 & 91 & 313 & 1,955 & 142 & 2,839 \\
\hline Vietnam & 19 & 161 & 173 & 590 & 344 & 162 & 1,095 \\
\hline Bangladesh & - & - & 323 & 1,106 & 4 & 268 & 1,109 \\
\hline Myanmar & - & - & 50 & 172 & 0 & 42 & 172 \\
\hline Brazil & - & - & 45 & 153 & 430 & 37 & 584 \\
\hline Thailand & 2 & 15 & 71 & 244 & 91 & 61 & 350 \\
\hline Nigeria $\ddagger$ & - & - & - & - & - & - & - \\
\hline Philippines & - & - & 8 & 28 & 373 & 7 & 401 \\
\hline Iran & 0 & 2 & 28 & 97 & 316 & 24 & 415 \\
\hline USA & 15 & 128 & 35 & 119 & 76 & 44 & 323 \\
\hline Egypt & 268 & 2,306 & 1 & 3 & 442 & 269 & 2,752 \\
\hline Pakistan & - & - & 8 & 28 & 0 & 7 & 28 \\
\hline $\begin{array}{l}\text { Taiwan Province } \\
\text { of China }\end{array}$ & 0 & 0 & 34 & 116 & 0 & 28 & 116 \\
\hline Russia & - & - & 57 & 194 & 71 & 47 & 265 \\
\hline Cambodia & 0 & 2 & 1 & 3 & 208 & 1 & 213 \\
\hline
\end{tabular}




$\begin{array}{lccccccc}\text { Uganda } & - & - & 6 & 19 & 67 & 5 & 86 \\ \text { Lao PDR } & 2 & 20 & 21 & 71 & 55 & 20 & 146 \\ \text { Turkey } & - & - & 0 & 0 & 268 & 0 & 268 \\ \text { Malaysia } & 12 & 101 & 3 & 12 & 50 & 15 & 162 \\ \text { Top 21 subtotal } & 1,188 & 10,219 & 4,851 & 16,586 & 9,903 & 6,039 & 36,709\end{array}$

$10 *$ Calculated by mean $\mathrm{CH}_{4}$ and $\mathrm{N}_{2} \mathrm{O}$ emission rates (Fig. 2) and the area for aquaculture

11 (Supplementary Table 6) collected from the literature. Rates of $\mathrm{CH}_{4}$ emission from rice-fish

12 system in Bangladesh were excluded when calculating ${ }^{30}$. $†$ Calculated by averaged

13 yield-scaled emission factor for $\mathrm{N}_{2} \mathrm{O}\left(\mathrm{EF}_{\mathrm{Y}}\right)$ (Fig. 2d) and volume of production from intensive

14 aquaculture. The direct emission rate of $\mathrm{CH}_{4}$ from intensive system was estimated at 0

15 according to $\mathrm{Hu}$ et al. $^{4}$. $\ddagger$ No official or private statistics is available about area and 16 production from different systems in Nigeria. 